\title{
Whole-body imaging in schwannomatosis
}

Figure Imaging
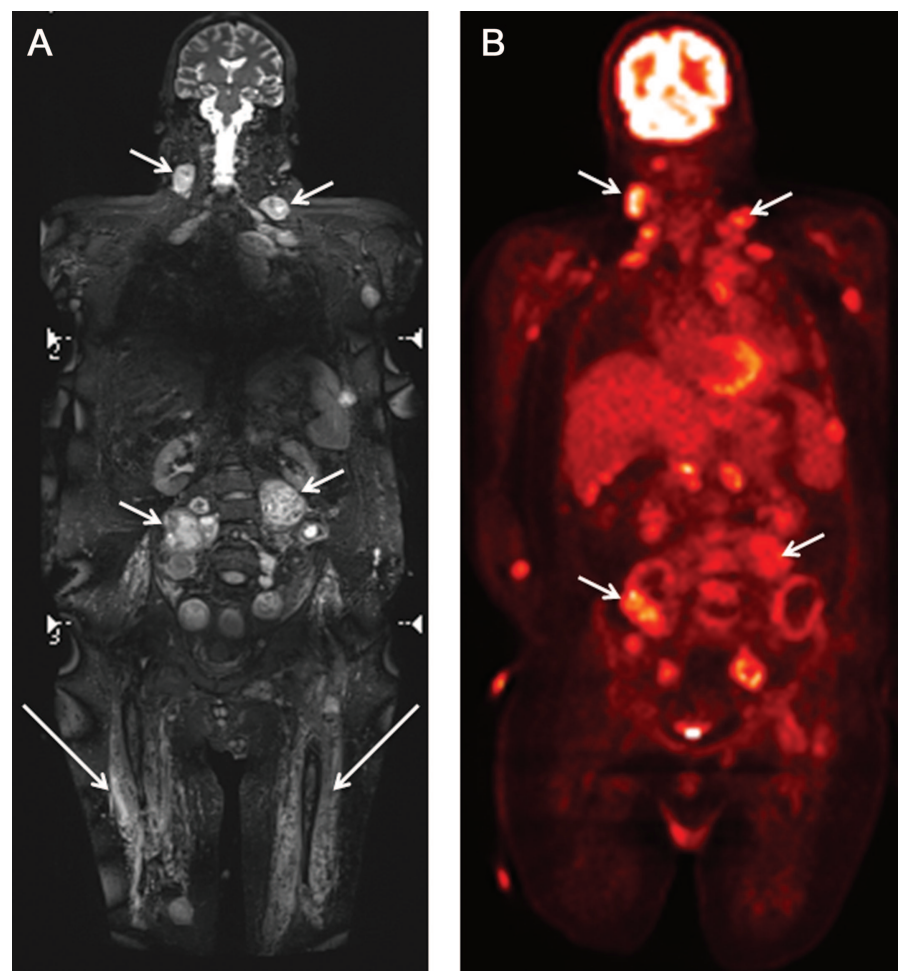

Coronal whole-body MRI (A) showing numerous mass lesions (short arrows) in a patient with schwannomatosis. FDG-PET (B) also shows the lesions, but MRI better depicts anatomy and displays lesions of any etiology regardless of FDG avidity. Muscle denervation (large arrows) is seen as edema-like T2 hyperintensity without perifascial edema on MRI.

A 23-year-old man with schwannomatosis ${ }^{1}$ was imaged with whole-body MRI and ${ }^{18} \mathrm{~F}$ FDG-PET to assess the extent of disease prior to initiating systemic therapy for new and growing tumors. The patient had undergone multiple prior resections of schwannomas from peripheral nerves. He had ongoing pain, diffuse dysesthesias, and bilateral upper extremity weakness. Assessment of disease burden was similar on both modalities (small arrows). MRI (figure, A) has superior demonstration of tumor localization and muscle denervation changes (large arrows) due to better contrast and spatial resolution than FDG-PET (figure, B). ${ }^{2}$ FDG-PET demonstrated avid uptake in these benign lesions.

\section{Avneesh Chhabra, MD, Jaishri Blakely, MD, Baltimore, $M D$}

Disclosure: Dr. Chhabra is a GE-AUR (GERRAF) fellow and has received research grants for MR neurography scans from Siemens Medical Solutions and Integra Life Sciences. Dr. Blakeley has served on a scientific advisory board for Novartis; receives research support from GlaxoSmithKline, the NIH/NCI, the Children's Tumor Foundation, Brain Tumor Funders Collaborative, and the American Society of Clinical Oncology; and has participated in medico-legal cases.

Address correspondence and reprint requests to Dr. Avneesh Chhabra, Johns Hopkins University, 601 N. Caroline St., Baltimore, MD 21287; achhabr6@jhmi.edu

1. Gonzalvo A, Fowler A, Cook RJ, et al. Schwannomatosis, sporadic schwannomatosis, and familial schwannomatosis: a surgical series with long-term follow-up. J Neurosurg Epub 2010 Oct 8.

2. Cai W, Kassarjian A, Bredella MA, et al. Tumor burden in patients with neurofibromatosis types 1 and 2 and schwannomatosis: determination on whole-body MR images. Radiology 2009;250:665-673. 


\title{
Neurology
}

\author{
Whole-body imaging in schwannomatosis \\ Avneesh Chhabra and Jaishri Blakely \\ Neurology 2011;76;2035 \\ DOI 10.1212/WNL.0b013e31821e55b0
}

This information is current as of June 6, 2011

\section{Updated Information \& Services}

\section{References}

Subspecialty Collections

Permissions \& Licensing

\section{Reprints}

including high resolution figures, can be found at: http://n.neurology.org/content/76/23/2035.full

This article cites 1 articles, 0 of which you can access for free at: http://n.neurology.org/content/76/23/2035.full\#ref-list-1

This article, along with others on similar topics, appears in the following collection(s):

\section{MRI}

http://n.neurology.org/cgi/collection/mri

Nerve tumor

http://n.neurology.org/cgi/collection/nerve_tumor

PET

http://n.neurology.org/cgi/collection/pet

Information about reproducing this article in parts (figures,tables) or in its entirety can be found online at:

http://www.neurology.org/about/about_the_journal\#permissions

Information about ordering reprints can be found online:

http://n.neurology.org/subscribers/advertise

Neurology ${ }^{\circledR}$ is the official journal of the American Academy of Neurology. Published continuously since 1951, it is now a weekly with 48 issues per year. Copyright Copyright (? 2011 by AAN Enterprises, Inc.. All rights reserved. Print ISSN: 0028-3878. Online ISSN: 1526-632X.

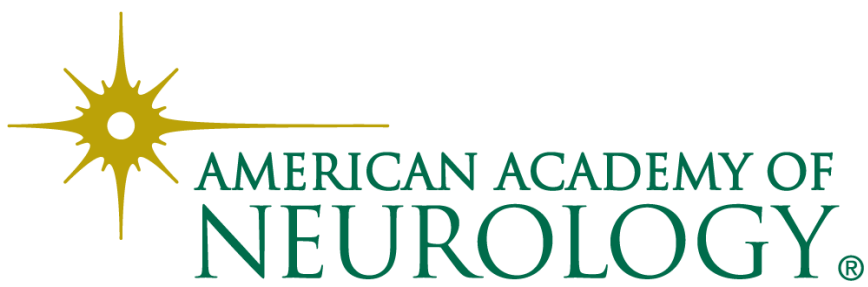

